\title{
Możliwości i ograniczenia stosowania wybra- nych strategii motywowania studentów w warsztacie pracy polonisty uniwersyteckiego
}

\author{
Capabilities and Limitations of Applying Chosen \\ Motivational Strategies for Students in Teaching \\ Polish Literature at University
}

\author{
|Karolina Górniak-Prasnal \\ Uniwersytet Jagielloński \\ IORCID: 0000-0001-5322-2828
}

\begin{abstract}
The article focuses on students motivation regarding the didactics of Polish Literature. The author recognizes possibilities and constraints of chosen motivation strategies, pointing out the specificity of Polish Literature as a field of study and the factors which determine the work with these students. Basing on her own didactic practices, the author proposes a few ideas of raising the level of motivation in the group of students, pursuing the virtuous cycle of learning, and improving their self-esteem. The text refers to different strategies of motivation based on the humanistic and constructivist paradigms and presents the advantages of applying the motivation-centred approach, in which the teacher reinforces the intrinsic motivation of students, respects their individual choices and, generally, make them the subjects of the whole learning process. The topic seems to be especially weighty in the context of return to stationary education after the coronavirus crisis.
\end{abstract}

Key words: didactics of Polish Literature, motivation, shift from teaching to learning, supportive assessment

Streszczenie: Tekst porusza problem motywacji u studentów polonistyki i kierunków pokrewnych. Autorka koncentruje się na możliwościach i ograniczeniach wybranych strategii motywowania, zwracając uwagę na specyfikę kierunku studiów i uwarunkowania pracy ze studentem polonistyki. W oparciu o własną praktykę dydaktyczną przedstawia propozycje działań, które mogą wpłynąć na podniesienie motywacji studentów, zrealizowanie budującego cyklu uczenia się, ale także poprawę samooceny i wzmacnianie pozytywnych przekonań o własnym potencjale. Odwołuje się do strategii motywowania opartych na modelach humanistycznym i konstruktywistycznym, przedstawiając korzyści, jakie dla dydaktyki polonistycznej może przynieść podejście oparte na wzmacnianiu wewnętrznej motywacji studenta i respektowaniu jego indywidualnych wyborów - a więc uczynienie go podmiotem procesu uczenia się. Zagadnienie to zasługuje na szczególny namysł w kontekście powrotu do nauczania stacjonarnego po kryzysie pandemicznym.

Słowa kluczowe: dydaktyka polonistyczna, motywacja, ocenianie wspierające, zwrot od nauczania do uczenia się 
Marzeniem każdego nauczyciela akademickiego jest współpraca z silnie zmotywowaną i pozytywnie nastawioną do nauki grupą studentów, a jednym z najtrudniejszych doświadczeń może okazać się poczucie bezradności w kontakcie z osobami o niskiej motywacji, obojętnymi wobec stawianych im wyzwań lub przekonanymi, że studiowanie ich przerasta. Motywacja, choć różnie definiowana w literaturze, oznacza zwykle gotowość jednostki do działania, w tym przypadku do procesu uczenia się. Z tego punktu widzenia warunkuje skuteczność owego procesu i jego efektywność, wpływa na poczucie satysfakcji z wykonywanych zadań oraz pomaga radzić sobie $\mathrm{z}$ ewentualnymi trudnościami $\mathrm{w}$ drodze do celu (Porzucek-Miśkiewicz, Wawrzyniak 2018, 117) ${ }^{1}$. Rzecz jasna, jako nauczyciele nie mamy wpływu na wszystkie czynniki decydujące o poziomie motywacji naszych studentów (do takich należą m.in. czynniki osobiste, rodzinne, społeczne, zdrowotne). Mimo to można i warto zawalczyć o podniesienie poziomu motywacji uczestników naszych zajęć, z wykorzystaniem wybranych strategii i metod pracy. W niniejszym tekście skupię się na możliwościach i ograniczeniach w zakresie motywowania adeptów polonistyki, zwracając uwagę na specyfikę tego kierunku studiów i uwarunkowania pracy studenta zarówno podczas zajęć, jak i poza nimi. Temat ten wiąże się z szerszym zagadnieniem, jakim jest sposób myślenia studentów polonistyki o sobie samych, o swojej roli na rynku pracy i w społecznościach, do których należą, a w jeszcze bardziej ogólnym sensie - odnosi się do ważkiego dziś pytania o miejsce humanistów we współczesnym społeczeństwie zachodnim (Nussbaum 2016).

W badaniach nad dydaktyką akademicką coraz więcej mówi się obecnie o konieczności dokonania zwrotu od modelu nauczania w stronę modelu uczenia sie - shift from teaching to learning (Sajdak-Burska 2013, 282295). O ile ten pierwszy opiera się na przekazywaniu wiedzy i niepodważalnym niekiedy autorytecie nauczyciela, a także wzmożonej kontroli ucznia, o tyle ten drugi koncentruje się na osobie uczącej się i wspieraniu jej w procesie uczenia się. W tym modelu konstruowanie przez studenta wiedzy zdecydowanie dominuje nad jej biernym przyswajaniem (Sajdak 2014, 48-50). Uczenie się (learning) wymaga też nieco innych, specyficznych strategii motywowania. Tradycyjny i - miejmy nadzieję - raczej powoli już odchodzący w przeszłość system kar i nagród, generujący w wielu wypadkach tzw. niszczący cykl uczenia się (porażka - krytyka - brak wiary w siebie - spadek motywacji) zostaje tu zastąpiony cyklem budującym (sukces - wzmocnienie - wiara w siebie - wzrost motywacji). Zależności te w kontekście motywacji charakteryzuje Geoff Petty (2010, 50-54). Stwarzając sprzyjające warunki do osiągnięcia przez studenta zamierzonego celu, zwiększamy jego szansę na odniesienie sukcesu, a przez to jego poczucie sprawczości i samoocenę, co z kolei zachęca do podejmowania dalszych, być może bardziej wymagających wyzwań. W dalszej części tekstu przedstawię swoje spostrzeżenia

${ }^{1}$ Autorki, określając motywację jako „siłę napędową ludzkich zachowań”, odwołują się do łacińskiej etymologii tego słowa związanej z ruchem, działaniem (łac. motivus - ruchomy). 
dotyczące tego, w jaki sposób nauczyciel akademicki na polonistyce (i kierunkach pokrewnych) może dążyć do zrealizowania tego budującego schematu, a tym samym zwiększyć nie tylko poziom motywacji swoich studentów, lecz także satysfakcję z zajęć (własną oraz uczestników). Opierać się będę w tym zakresie na własnym kilkuletnim doświadczeniu dydaktycznym, a także na informacjach zwrotnych otrzymanych od osób uczestniczących w moich zajęciach.

Jako doktorantka, a następnie asystentka na Wydziale Polonistyki Uniwersytetu Jagiellońskiego, prowadziłam dotąd głównie zajęcia o charakterze ćwiczeń lub warsztatów. Jak wiadomo, spotkania tego rodzaju - szczególnie te z zakresu historii literatury bądź poetyki czy teorii literatury - koncentrują się zwykle na wspólnej pracy z tekstem (literackim, krytycznoliterackim lub teoretycznoliterackim, niekiedy filozoficznym) pod kierunkiem nauczyciela i stanowią funkcjonalną całość z przekazującymi wiedzę wykładami oraz pracą własną studenta po godzinach zajęć. Praca poza salą dydaktyczną (lub platformą e-learningową) zwykła obejmować samodzielną krytyczną i uważną lekturę tekstów przewidzianych w sylabusie. Sądzę, że to właśnie ten ostatni element stanowi fundament studiowania polonistyki, a jakość samodzielnej pracy przekłada się na późniejsze osiągnięcia egzaminacyjne i dyplomowe. Dlatego niezwykle istotne wydaje się położenie nacisku na ten element studiów polonistycznych. Nie chodzi tu jednak o zwiększenie kontroli, lecz o kształtowanie umiejętności samodzielniej pracy - warto, byśmy pokazywali studentom, w jaki sposób można efektywnie wykorzystać cenny czas indywidualnej lektury, jakie strategie czytania i uczenia się warto wdrożyć, a także jak pracować nad samodyscypliną. Jeśli studenci dostrzegą, że to oni sami mają największy wpływ na swoje osiągnięcia i że w dużej mierze mogą kształtować swoją własną ścieżkę rozwoju i zainteresowań, ich motywacja do studiowania może znacząco wzrosnąć ${ }^{2}$. Projektowanie własnej drogi studiowania literatury rozpoczyna się właśnie wówczas, gdy dokonują oni samodzielnych, być może zainspirowanych niekiedy przez nauczyciela poszukiwań. Równie ważna będzie dla nich jednak nasza gotowość do wspierania tego rozwoju, służenie radą czy pomocą, gdy zajdzie taka potrzeba.

Aby skutecznie dbać o motywację studentów, z którymi spotykamy się na zajęciach, warto odpowiedzieć na kluczowe w tym kontekście pytanie o to, co skłoniło ich do podjęcia właśnie tych, a nie innych studiów. Odpowiedź na to pytanie w odniesieniu do polonistyki wydaje się trywialna: oczywiście pasja do czytania literatury. Jednak, jak pokazuje praktyka dydaktyczna

\footnotetext{
${ }^{2}$ Sprzyja temu coraz powszechniejsza praktyka konstruowania takiego programu studiów, który uwzględnia owe indywidualne ścieżki rozwoju, a wręcz skłania studenta do wyboru określonej liczby kursów czy modułów z dostępnej puli - szczególnie na studiach drugiego stopnia. Program kierunku polonistyka-komparatystyka, na którym uczę, opiera się (na obu stopniach) na autorskich kursach tzw. literatury porównawczej - są one regularnie zmieniane lub aktualizowane, przez co jesteśmy w stanie odpowiadać na potrzeby i zainteresowania studentów, ale i umożliwić im wybór własnej ścieżki spośród wielu możliwości uprawiania współczesnej komparatystyki. Zob. sylabusy dla kierunku polonistyka-komparatystyka na Uniwersytecie Jagiellońskim: https://sylabus.uj.edu.pl/ pl/2/1/2/21/96 (dostęp 9.06.2021).
} 
wielu polonistów akademickich, jest to sprawa o wiele bardziej złożona, a czytelnicza pasja nie jest z pewnością jedyną przyczyną wyboru polonistyki i raczej nie jest warunkiem sine qua non powodzenia na tych studiach - niemniej z pewnością wpływa na to, czy i jak bardzo te studia nas satysfakcjonują. Niekiedy dopiero rodzi się ona w ich trakcie, a niekiedy, niestety, wypala się i obumiera. Uważam, że warto zwrócić baczniejszą uwagę na to, co dzieje się z literackimi pasjami w trakcie kilku lat obecności studenta czy studentki w murach akademii. Rozmowa z uczestnikami naszych zajęć o tym, jak zmienia się ich zainteresowanie literaturą na poszczególnych latach studiów i co wpływa na te zmiany, może przynieść nam istotną informację zwrotną, pozwalającą udoskonalić nasze zajęcia, ale może być też dla nich samych okazją do ważnej autorefleksji. Wydaje się, że oprócz niewątpliwie istotnego czynnika motywującego, jakim jest dla adepta polonistyki żywe zainteresowanie literaturą i czerpanie przyjemności z poznawania jej, nie mniej znaczącą cechą byłaby wytrwałość w radzeniu sobie z lekturą dużej liczby tekstów, często w dość szybkim tempie.

Orientacje motywacyjne oraz typy jej regulacji charakteryzuje w swoim artykule Damian Grabowski, wyróżniając amotywację, motywację zewnętrzną oraz motywację wewnętrzną, o których pisze w odniesieniu do zjawiska autodeterminacji lub jej braku (2014, 265-296). Gdyby spróbować odnieść zarysowaną powyżej (choć z konieczności subiektywną, bo opartą na własnym doświadczeniu) specyfikę studiów polonistycznych do wyróżnianych przez badaczy typów motywacji, można by uznać, iż motywacja do studiowania literatury u adepta polonistyki powinna mieć charakter wewnętrzny i autonomiczny. Wydaje się bowiem, że gdy zabraknie owych wewnętrznych pobudek, pozostałe czynniki, zwłaszcza te o charakterze zewnętrznym, mogą okazać się nieskuteczne. Ze względu na specyfikę kierunku niełatwo przekonać studentów o korzyściach z posiadania polonistycznego wykształcenia na rynku pracy - choć to utarte i krzywdzące przekonanie uznać dziś należy raczej za szkodliwy mit, a w codziennej dydaktyce staramy się pokazywać studentom, że kompetencje, jakie nabywa polonista w trakcie studiów, są cenione przez pracodawców w wielu branżach. Mimo to raczej trudno odwoływać się również do prestiżu zawodu, co zdaje się dość oczywiste w przypadku takich kierunków jak prawo czy medycyna. Słowem - bez dość wysokiej indywidualnej motywacji studenta nauczyciel stanie przed dużym wyzwaniem, by skutecznie i satysfakcjonująco poprowadzić go przez proces uczenia się. Jak zatem projektować i prowadzić zajęcia, aby młodzi czytelnicy i miłośnicy literatury byli dobrze zmotywowani do dalszego rozwoju? Jak zapobiec utracie pasji, swoistemu „wypaleniu" młodych polonistów (któremu sprzyjają przeładowane niekiedy lub nieefektywne sylabusy)? Jakie ograniczenia można napotkać na tej drodze? Spróbuję na te pytania odpowiedzieć, przedstawiając strategie motywowania sprawdzone podczas moich zajęć, a następnie omawiając własne problemy na tym polu. Na koniec scharakteryzuję kilka niekonwencjonalnych 
sposobów aktywizacji i motywowania studentów, które można wypróbować w kształceniu polonistycznym.

Już z perspektywy kilku lat pracy na uniwersytecie dostrzec można, jak ważnym czynnikiem motywującym dla studentów jest rozpoznanie ich potrzeb, celów i oczekiwań. Dobrze sprawdza się tutaj praktyka zapoznawczej rozmowy na pierwszych zajęciach danego kursu - zwykle pojawiają się pytania o to, czego uczestnicy się spodziewają po danym kursie, dlaczego go wybrali (w przypadku zajęć fakultatywnych) lub co ich przywiodło na kierunek polonistyczny, a także co chcieliby na tych studiach osiągnąć. Taka strategia wydaje się istotnym elementem budowania wzajemnego zaufania na linii prowadzący-student, daje uczestnikom kursu przekonanie, że respektujemy ich zainteresowania i oczekiwania (Danilewska 2004, 59-65). W zależności od rodzaju kursu - oraz na ile to możliwe - warto skonsultować ze studentami wybór tematów z listy zagadnień przewidzianych w sylabusie i z uwagą podejść do ich propozycji przy planowaniu zajęć na początku semestru. W przypadku studiów polonistycznych zwykle jest to możliwe szczególnie w zakresie wyboru literatury czytanej na zajęciach. Równie ważnymi sygnałami dla jakości naszej komunikacji ze studentami będzie uważność na wszelkie sugestie co do formy zajęć, a po zakończonym kursie - analiza tych form z punktu widzenia tego, czy pobudziły aktywność studentów, czy też się nie sprawdziły i dlaczego.

Nieustannie podkreśla się, jak ważne - także z perspektywy mechanizmów motywacji -jest indywidualne podejście nauczyciela do każdego studenta. Oczywiście stopień tej indywidualizacji bezpośrednio zależy od liczebności grupy (która niestety często jest zbyt duża, by móc efektywnie działać na tym polu). Ważnym przejawem skupienia nauczyciela na jednostce jest ocenianie wspierające, a więc praktyka opatrywania każdej oceny komentarzem (pisemnym bądź ustnym), by podkreślić jej postępy i wskazać, co jeszcze można poprawić (Petty 2010, 433-456). Dość oczywistym standardem - oprócz sumiennego przygotowania się do zajęć - wydaje się regularne reagowanie na studenckie wiadomości, a także postawa szacunku, życzliwości i otwartości. Okazało się to jednak szczególnie ważne w okresie nauki zdalnej, podczas którego komunikacja internetowa stała się podstawowym i w zasadzie jedynym możliwym sposobem na nawiązanie kontaktu. Z konieczności i w konsekwencji przejścia na zdalny tryb nauczania osłabieniu ulec musiały nasze relacje $\mathrm{z}$ uczestnikami zajęć, a w przypadku studentów pierwszego roku często trudno mówić o ich rzeczywistym nawiązaniu. W tych kryzysowych warunkach kluczowa dla motywacji i pozytywnego nastawienia studentów często okazywała się świadomość, że mogą otrzymać naszą pomoc i zwrócić się do nas z każdym pytaniem, a w trudnych sytuacjach liczyć na bardziej elastyczne podejście np. do kwestii terminów. Choć z jednej strony z punktu widzenia motywacji ważna jest konsekwencja nauczyciela $\mathrm{w}$ przestrzeganiu np. terminu oddania pracy, na który umówiliśmy się ze studentami, to doceniają oni naszą zgodę na 
zrobienie uzasadnionego wyjątku. Liczy się to, że dostrzegamy ich wysiłki - dlatego tak ważne jest docenianie ich aktywności (za pomocą „plusów”, ale też słownych pochwał), niepozostawianie zleconych zadań bez komentarza zwrotnego, podkreślanie postępów, jakich pod naszą opieką dokonują.

Dobrym laboratorium strategii motywacyjnych oraz ważnym miejscem przygotowania młodego nauczyciela do roli opiekuna naukowego (np. na seminarium dyplomowym) może się okazać niedoceniany chyba kurs warsztatowy, określany często jako „nauki pomocnicze” czy „podstawy warsztatu literaturoznawczego". Z reguły ma on charakter warsztatów właśnie, a co za tym idzie, mamy szansę pracować na nim w nieco mniejszych grupach i znaleźć więcej przestrzeni na indywidualne działania z każdym ze studentów, być może nawet wypróbować techniki tutoringowe. Prowadzony przeze mnie kurs o takim charakterze przeznaczony jest dla studentów I roku polonistyki-komparatystyki i ma charakter pomocniczy względem głównego kursu historii literatury staropolskiej (prowadzonego przez inną osobę), który wieńczy obszerna praca roczna. Staram się zatem pełnić funkcję trenerki, który doradza i zachęca do dalszej pracy, wspierając studentów w realizacji tego zadania (Dziedziczak-Foltyn 2018, 113-123). Pokazuję, że projekt ten - choć wydaje się bardzo ambitny, a niektórym osobom wręcz nieosiągalny - jest możliwy do wykonania. Musimy jednak wskazać naszym studentom sprawdzone praktyki $\mathrm{w}$ zakresie warsztatu literaturoznawczego, które pozwolą im odnieść sukces. Nie chodzi tu oczywiście wyłącznie o przedstawienie podstaw tego zagadnienia, jak $\mathrm{np}$. zasady tworzenia aparatu badawczego, lecz także - na dalszych etapach - o pozostawanie w gotowości do pomocy w udoskonalaniu owego warsztatu, kwerendach bibliotecznych i internetowych, doborze źródeł. Studentów szczególnie interesują takie zagadnienia, jak umiejętności planowania własnej pracy i uczenia się, a także sposoby radzenia sobie z potencjalnymi trudnościami w tym zakresie - warto poświęcić tym pozornie pobocznym zagadnieniom odpowiednią ilość czasu, zwłaszcza obecnie, w dobie wszechobecnych elektronicznych rozpraszaczy i problemów z koncentracją.

Model kształcenia, do którego - jak sądzę - warto dążyć w dydaktyce polonistycznej, to paradygmat humanistyczny lub konstruktywistyczny, a więc raczej wspieranie w samodzielnym rozwoju studenta aniżeli surowe egzekwowanie narzuconych, sztywnych zasad, co z kolei stanowi istotę podejścia behawioralnego (Sajdak-Burska 2018, 13-26; Sajdak 2013, 303428). Przemawia za tym specyfika naszej dyscypliny, opartej w dużej mierze na pracy własnej, na indywidualnych poszukiwaniach i szukaniu nowych rozwiązań, na twórczym przetwarzaniu dorobku myśli humanistycznej. Autorską próbą pójścia w tym kierunku było wprowadzenie samosprawdzających anonimowych ankiet monitorujących postęp prac nad omawianym wyżej pisemnym projektem z historii literatury. Wprowadzenie tej metody na zajęciach z podstaw warsztatu literaturoznawczego sprawiło, że studenci sami $\mathrm{w}$ trakcie semestru zostali nakłonieni do autorefleksji 
i planowania dalszych działań, a jednocześnie mieli możliwość zasygnalizowania prowadzącej swoich oczekiwań lub obaw (Górniak-Prasnal 2021). Wydaje mi się to dobrym sposobem na „miękkie” dopingowanie studentów. Zamiast perspektywy kary za niewykonanie zadania mogą dostrzec, że na wykonanie projektu oni sami mają największy wpływ, a nauczyciel służy im wskazówkami. Metoda spotkała z aprobatą studentów i może się sprawdzić w szczególności na seminariach dyplomowych.

Motywację studentów podnosi również wskazywanie, w jaki sposób treści danego kursu mogą stać się przydatne w przyszłej pracy. Z perspektywy polonisty jako kluczowe kompetencje można wymienić zdolność krytycznego, pogłębionego rozumienia tekstów kultury, umiejętność prowadzenia dyskusji z trafnym doborem argumentów czy sprawne komunikowanie się w mowie i piśmie. Te umiejętności mogą okazać się znaczącym walorem $\mathrm{w}$ wielu branżach, niekoniecznie związanych z literaturą. Warto tę kwestię akcentować w sposób szczególny, by zapobiec sytuacji, w której nasi studenci przejawiają niską samoocenę na skutek wciąż aktualnego ogólnego przekonania o niskim prestiżu wykształcenia polonistycznego w społeczeństwie. Osobiście dzielę się na zajęciach swoim doświadczeniem zawodowym jako redaktorka i korektorka. W przypadku kierunku często deprecjonowanego w obiegowych opiniach (jako takiego, po którym rzekomo „nie ma pracy”) niezwykle ważne jest pozytywne wzmacnianie studentów i starania o to, by ich samorozwojowi towarzyszyła wiara we własne możliwości i kompetencje.

Nasze wysiłki w kierunku zwiększenia motywacji studentów napotykają jednak rozmaite przeszkody - wiele z nich należy do powszechnych problemów dydaktyki uniwersyteckiej, tutaj jednak skupię się na tych, które wynikają ze specyfiki studiów polonistycznych. O podstawowym, wewnętrznym źródle motywacji dla studentów polonistyki mówiłam już we wstępie. Prócz tego warto zwrócić uwagę, że na niektórych kursach (zwłaszcza ukierunkowanych teoretycznie) trudno przekonać studentów, że wiedza z nich wyniesiona zaprocentuje w przyszłości, gdyż nie widzą jej bezpośredniego i konkretnego przełożeniana swoją zawodową przyszłość. Kursy te uczą jednak bardziej podstawowych (a przez to notabene uniwersalnych) kompetencji jak sztuka krytycznego myślenia czy argumentowania. Sposobem na tę barierę może być pokazywanie omawianych zagadnień i tekstów w świetle rzeczywistości, która bezpośrednio dotyczy społeczności studenckiej - w przypadku kursów poświęconych literaturze mogą to być np. nawiązania do bieżących wydarzeń na rynku wydawniczym, do życia literackiego, ale także do ważnych i aktualnych spraw społecznych czy kulturowych.

Czynnikiem obniżającym motywację może być fakt, że niektóre zajęcia w toku kształcenia polonistycznego niejako programowo nie kończą się jednoznacznymi wnioskami, nauczyciel nie rozstrzyga podjętych kwestii, a nawet czasem je świadomie komplikuje. Tego rodzaju „ćwiczenia z myślenia” mogą się jednak okazać kluczowe w procesie kształcenia polonisty. 
Co więcej, na ćwiczeniach zakładających pogłębioną interpretację tekstu metody aktywizujące typu quizy, gry czy chmury słów i szybkie testy obejmujące jedynie wiedzę pamięciową sprawdzają się tylko w ograniczonym stopniu - raczej jako uatrakcyjnienie zajęć lub wstęp do dyskusji. Pewnym rozwiązaniem może być zwrot w stronę stawiania otwartych, prowokujących pytań (bez szybkich, prostych odpowiedzi), dzięki którym omawiany temat będzie rezonował w uczestnikach zajęć po ich zakończeniu, a może nawet zachęci do dalszych poszukiwań. Nie jest to proste zadanie dla nauczyciela - wymaga bowiem odwagi przyznania się do tego, że niektóre kwestie pozostają dyskusyjne, czasem też do własnej niepewności. Wymaga zrewidowania własnych przeświadczeń na temat literatury i chęci pokazania studentom takiej jej wizji, w której staje się ona intelektualną przygodą, a jej interpretacja przestaje być biernym odkrywaniem zakodowanych $\mathrm{w}$ dziele sensów, stając się raczej ich konstruowaniem i negocjowaniem we wspólnocie interpretacyjnej, którą tworzymy razem z uczestnikami zajęć (Fish 2002, 81-98; Cieślak-Sokołowski 2012, 86-92).

Studenci, którzy przychodzą na studia wyższe, opuściwszy mury polskiej szkoły, często niestety przejawiają nader wysoki poziom samokrytycyzmu i obawę przed popełnieniem błędu. Obserwuję tę tendencję jedynie jako nauczycielka na kierunkach polonistycznych, trudno więc o wysnuwanie ogólnych wniosków, ale na przykładzie grup, z którymi miałam przyjemność pracować, mogę stwierdzić, iż zjawisko to jedynie się pogłębiło w okresie nauki zdalnej. Studenci niechętnie podchodzą np. do pomysłu wzajemnego czytania swoich prac i rozmawiania o nich w małych grupach. Obawiają się zabrania głosu, który to gest jest dla nich jednoznaczny z wystawieniem się na ocenę innych (również współuczestników zajęć). Sądzę, że przy takich obserwacjach dość ostrożnie należy podchodzić do strategii motywacyjnych opartych na silnej rywalizacji i konkurencji. Zamiast pogoni za punktami i ocenami (do której i tak zmusza zarówno nas, jak i nauczycieli szkolnych system, w którym funkcjonujemy) postawmy na ocenianie wspierające. Co ważniejsze, skupiajmy się na pokazywaniu tego, co intrygujące i fascynujące w naszej dyscyplinie - na przykład do czego może służyć uważna, krytyczna lektura tekstów, do jakich, często niespodziewanych miejsc może nas ona zaprowadzić, jakie są związki literatury z naszym własnym życiem.

Studenci pierwszego roku wyraźnie dostrzegają, czym różni się kształcenie polonistyczne na etapie szkolnym od studiów w tym kierunku na uniwersytecie i bardzo cenią sobie fakt, iż w akademii mamy znacznie więcej czasu i przestrzeni na interpretację i rozmowy o tekstach. Możliwość swobodnej dyskusji często wzbudza w młodych ludziach entuzjazm - jednak można zauważyć, że nieraz skutkuje także pewną obawą przed tym, co nieznane lub nierozstrzygalne. Studenci nieraz nie od razu są gotowi do przedyskutowania jakiejś śmiałej, kontrowersyjnej tezy na temat literatury. Pewien wpływ ma tu zapewne obecny model edukacji szkolnej, oparty na silnym autorytecie nauczyciela i dyktaturze „klucza odpowiedzi”, 
co skutecznie dusi ambicje samodzielnego szukania rozwiązań. Zamyka to późniejszych studentów w bezpiecznej strefie oczywistych pytań i odpowiedzi, które nie pozostawiają miejsca na interpretację. Warto nad tym pracować, dając przede wszystkim pole do otwartej wymiany myśli, stwarzając przyjazną - bezpieczną emocjonalnie - przestrzeń na zajęciach i pokazując korzyści, jakie może przynieść zmiana utartych schematów myślenia.

Ostatnim - choć na pewno nie najmniej ważnym - czynnikiem negatywnie oddziałującym na motywację studentów polonistyki jest przeciążenie ilością materiału. Wciąż wiele osób z tego powodu rezygnuje ze studiowania, mimo że staramy się modyfikować program studiów tak, by dostosować go do zmiennej rzeczywistości kulturowej i potrzeb oraz możliwości pokolenia cyfrowej rewolucji. Problem ten stał się szczególnie palący w dobie pandemii, gdy wszyscy zostaliśmy zmuszeni, by w dużym stopniu zastąpić książkę papierową dokumentem elektronicznym. Dobrym pomysłem w tym kontekście wydaje mi się wspieranie studentów w pracy nad własną koncentracją i umiejętnością efektywnego czytania - elementy tych technik są wprowadzane na naszym wydziale (Całek 2014, 295-305).

Repertuar strategii motywacyjnych, które mogą się sprawdzić w pracy ze studentami polonistyki, nie ogranicza się oczywiście do kilku wymienionych metod charakterystycznych dla modelu humanistycznego czy konstruktywistycznego. Ważne, by dostosować nasze podejście do specyfiki grupy i możliwości, którymi dysponujemy. Idealną sytuacją byłaby ta, w której jako nauczyciele bylibyśmy w stanie uważnie dobierać strategie motywowania do zainteresowań, potrzeb i kompetencji danej osoby (Sajdak 2014, 52-56; Grabowski 2014, 281-291). To szczególnie ważne na zajęciach seminaryjnych, służących przygotowaniu dużego projektu badawczego, jakim jest praca licencjacka czy magisterska. Niektóre osoby mają bardzo skonkretyzowaną ścieżkę rozwoju, same proponują tematy i rozwiązania - w takich przypadkach wystarczy życzliwe "dopingowanie” nauczyciela, obserwowanie i wspieranie ich rozwoju, afirmowanie prawa do własnych wyborów czy pomysłów. Inni z kolei potrzebują i oczekują większego ukierunkowania, dobrze funkcjonują wówczas, gdy oferujemy im sporo wskazówek i pokazujemy różne możliwości. To pozwala im zdecydować, czym chcą się zajmować lub w zadowalający dla nich samych sposób pokierować swoim projektem. W przypadku obu tych grup praca nad motywacją jej uczestników będzie zgoła różna. Podobnie wygląda kwestia zarządzania czasem: jedni potrzebują sztywnych terminów i mobilizowania do pracy, drugich silna presja czasowa blokuje w działaniu i wymagają bardziej elastycznego podejścia. Pomiędzy biegunami kontroli i autonomii rozciąga się zatem cały wachlarz różnych rozwiązań, wśród których możemy elastycznie i z poszanowaniem podmiotowości studenta wybierać te, które dla obu stron będą najbardziej satysfakcjonujące (Grabowski 2014, 281-291) ${ }^{3}$.

${ }^{3}$ Autor artykułu wymienia i charakteryzuje wymiary zachowań wykładowcy (sytuujące się między biegunami wzmożonej kontroli i szerokiej autonomii - od eksperta do leseferysty) oraz odpowiadające im metody prowadzenia zajęć i typy motywacji. 
Oprócz wstępnego rozpoznania potrzeb ważne jest wsłuchiwanie się w głos samych zainteresowanych. Myślę tu nie tylko o roli końcowych ankiet satysfakcji studenckiej, które - pomijając wszelkie minusy tego systemu - są dla nas oczywiście istotną informacją zwrotną i każdego roku pozwalają udoskonalać metody pracy (Jacko i in. 2020). Często jednak okres wypełniania przez studentów ankiet, przypadający na koniec semestru, jest momentem zbyt późnym, by w danym kursie i z daną grupą móc jeszcze cokolwiek zmienić. Dlatego warto, niejako zapobiegając poczuciu rozczarowania uczestników formą czy treścią zajęć, pomyśleć o zbadaniu ich satysfakcji w trakcie semestru - za pomocą krótkiej ankiety lub, w przypadku grup bardziej otwartych na dialog, rozmowy na temat kształtu zajęć, z prośbą o ich ocenę i sugestie zmian. Świadomość, że zdanie studentów ma bezpośrednie przełożenie na to, jak wyglądają zajęcia, jak pracujemy z tekstem i jak je dobieramy, może być istotnym motywatorem na dalszą część semestru.

Warto zastanowić się nad możliwościami, jakie przynosi metoda projektów (Project Based Learning) i podejmować próby przekształcenia niektórych ćwiczeń - zwłaszcza tych koncentrujących się na interpretacji tekstów - z klasycznej formy będącej zwykle połączeniem miniwykładu i pogadanki heurystycznej w model w większym stopniu aktywizujący studentów (Strawa-Kęsek 2015; Fiszbak (red.) 2019). Praca metodą projektów, choć wydaje się początkowo trudna do wdrożenia lub czasochłonna, umożliwia studentom podjęcie realnych działań interpretacyjnych i badawczych, rozwija kompetencje konieczne do efektywnej współpracy w grupie, daje poczucie sprawczości i szansę realnego poznania pracy literaturoznawcy - w miejsce zajęć-pogadanek, w których udział studentów jest sporadyczny i woluntarystyczny, a nauczyciel może łatwo wpaść w pułapkę monologizowania (Kosz 2012, 97-116). Potrzeba zwiększenia zakresu zajęć warsztatowych, na których uczestnicy mogliby samodzielnie zrealizować większy projekt, pojawia się w głosach samych studentów i sądzę, że metoda projektów byłaby dobrą odpowiedzią na takie oczekiwania dzisiejszych studentów polonistyki ${ }^{4}$.

Nie oznacza to jednak, że klasyczna akademicka dyskusja odchodzi do lamusa - przeciwnie, wciąż wydaje się ona fundamentem uniwersyteckiego kształcenia polonistycznego. Należałoby wręcz poświęcić jej więcej uwagi, skupiając się na krytycznej analizie metod, które obecnie stosujemy, tak aby polonistyczna dyskusja nie stawała się formą dalece spontaniczną i improwizowaną (choć i to ma swoje zalety). Warto na przykład wdrażać metodę pytań sokratejskich, a także zastanowić się nad wykorzystaniem zasad debaty oksfordzkiej na zajęciach. Innymi potencjalnie ciekawymi sposobami aktywizowania do dyskusji są takie rozwiązania jak burza mózgów, kolorowe kapelusze de Bono czy poker kryterialny. To metody

${ }^{4}$ Takie głosy pojawiły się wśród przedstawicieli społeczności studenckiej Wydziału Polonistyki UJ na tegorocznej wydziałowej debacie o jakości kształcenia zorganizowanej w ramach Tygodnia Jakości Kształcenia na UJ w dniu 15.04.2021 za pośrednictwem platformy Microsoft Teams. 
dobrze sprawdzające się w klasycznym nauczaniu stacjonarnym. Również pewne narzędzia, z których - bardziej z konieczności niż z własnego wyboru - korzystaliśmy $\mathrm{w}$ trakcie nauczania zdalnego, mogą wzbogacić sposoby dyskusji ze studentami. Ważną, a do niedawna chyba niedocenianą opcją jest internetowe forum dyskusyjne, które oferują uniwersyteckie platformy Moodle. Być może warto zastosować to narzędzie również w warunkach nauczania stacjonarnego - forum dyskusyjne może pomóc w zaktywizowaniu osób obawiających się publicznego zabrania głosu i chętniej wyrażających się w piśmie. Daje możliwość wykonywania w trakcie semestru krótkich ćwiczeń pisemnych, będących wprawką przed większym projektem, jak praca roczna czy dyplomowa. Aby jednak mogło się to powieść i aby forum „żyło”, trzeba umiejętnie dobrać tematy, które się na nim pojawią i aktywnie moderować dyskusję - dydaktycy podkreślają, że sprawdzają się tutaj zagadnienia szczególnie angażujące emocjonalnie lub niejednoznaczne, zmuszające do refleksji (Sajdak 2014, 61-62).

Okres stopniowego powrotu na uczelnię po kryzysie pandemicznym z pewnością będzie niósł ze sobą wiele wyzwań, a od nauczycieli będzie wymagał szczególnej elastyczności, otwartości i empatii względem studentów. Dla wielu z nich okres od marca 2020 jest czasem życiowego kryzysu i będą potrzebowali czasu, by wrócić do równowagi. Tym bardziej warto teraz zwrócić baczniejszą uwagę na ich potrzeby i oczekiwania oraz wdrażać metody, dzięki którym adepci polonistyki nie tylko zwiększą poziom swojej motywacji do nauki, lecz przede wszystkim będą mogli czerpać satysfakcję ze studiowania, a czytanie i badanie literatury pozostanie (lub stanie się) prawdziwą pasją, pozwalając jednocześnie rozwijać kompetencje przydatne w przyszłej karierze zawodowej. Podejście oparte na zaufaniu i wzmacnianiu wewnętrznej motywacji studenta, przy respektowaniu jego indywidualnych celów i wyborów, czyni go podmiotem procesu uczenia się - a to, jak sądzę, stanowi podstawę wszystkich strategii skutecznego motywowania i warunek obustronnego dydaktycznego sukcesu.

\section{Bibliografia:}

Całek Anita, 2014, Techniki efektywnego czytania i uczenia się $w$ dydaktyce uniwersyteckiej, w: Biedrzycki K., Bobiński W., Janus-Sitarz A., Przybylska R. (red.), Polonistyka dziś - ksztatcenie dla jutra, t. 3, Kraków.

Cieślak-Sokołowski Tomasz, 2012, Blisko tekstu: lektura krytyczna, dydaktyka uniwersytecka a teorie kulturowe, „Edukacja”, nr 2.

Danilewska Joanna, 2004, Zaufanie $w$ relacji nauczyciel akademicki-student, w: Skulicz D. (red.), W poszukiwaniu modelu dydaktyki akademickiej, Kraków.

Dziedziczak-Foltyn Agnieszka, 2018, Tutoring, coaching, mentoring w edukacji wyższej - potrzeba instytucjonalizacji metod i profesjonalizacji kompetencji, w: Maciejowska I., Sajdak-Burska A. (red. nauk.), Rozwijanie kompetencji dydaktycznych nauczycieli akademickich. Wybrane praktyki, Kraków. 
Fish Stanley, 2002, Jak rozpoznać wiersz, gdy się go widzi, w: Interpretacja, retoryka, polityka. Eseje wybrane, Grzeliński A. (przeł.), Kraków.

Grabowski Damian, 2014, Jak motywować studentów? Próba udzielenia odpowiedzi w świetle teorii autodeterminacji Richarda Ryana i Edwarda Deciego, w: Kożusznik B., Polak J. (red.), Uczyć z pasja. Wskazówki dla nauczycieli akademickich, Katowice.

Jacko Jan F., Szczepaniak Daniel, Szewczyk Tomasz, Śliwa Agnieszka, 2020, Niektóre determinanty ocen $w$ ankietach studenckich a kompetencje dydaktyków. Przyczynek do dyskusji, w: Sajdak-Burska A., Maciejowska I. (red.), Profesjonalizacja roli nauczyciela akademickiego, Kraków.

Kosz Justyna, 2012, „Sukces niejedno ma imię”. Metoda projektów jako jedna ze strategii rozwijania poczucia sprawstwa i nabywania kompetencji uczniów do współpracy, „Forum Dydaktyczne”, nr 9/10.

Nussbaum Martha, 2016, Nie dla zysku. Dlaczego demokracja potrzebuje humanistów, Pawłowski Ł. (przeł.), Warszawa.

Petty Geoff, 2010, Motywacja, w: Nowoczesne nauczanie. Praktyczne wskazówki i techniki dla nauczycieli, wykładowców i szkoleniowców, Bartosik J. (przeł.), Sopot.

Polonistyczna dydaktyka ogólna, 2019, Fiszbak J. (red.), Łódź.

Porzucek-Miśkiewicz Maria, Wawrzyniak Sonia, 2018, O funkcjach motywacji w dydaktyce akademickiej, „Pedagogika Szkoły Wyższej”, nr 2.

Sajdak Anna, 2014, Sztuka motywowania w edukacji zdalnej skoncentrowanej na uczniach, w: Ku dobrej szkole skoncentrowanej na uczniach, Kuźma J., Pułka J. (red. nauk.), t. 2, Kraków.

Sajdak-Burska Anna, 2013, Paradygmaty dydaktyki akademickiej, w: Paradygmaty kształcenia studentów i wspierania rozwoju nauczycieli akademickich, Kraków.

Sajdak-Burska Anna, 2018, Paradygmat humanistyczny w dydaktyce akademickiej - utopia, konieczność, szansa?, „Pedagogika Szkoły Wyższej”, nr 2.

Strawa-Kęsek Ewelina, 2015, Metoda projektu w edukacji polonistycznej, Kraków.

Dokumenty elektroniczne:

Górniak-Prasnal Karolina, 2021, ankieta na Microsoft Forms Praca roczna - work in progres (?), https://tiny.pl/r6bbm (dostęp 6.05.2021).

Sylabusy dla kierunku polonistyka-komparatystyka na Uniwersytecie Jagiellońskim,2021, https://sylabus.uj.edu.pl/pl/2/1/2/21/96 (dostęp 9.06.2021).

\section{O Autorce:}

Karolina Górniak-Prasnal - dr, asystent w Katedrze Komparatystyki Literackiej na Wydziale Polonistyki UJ w Krakowie. Zainteresowania naukowe: polska i anglojęzyczna poezja XX i XXI wieku, awangarda i modernizm, eksperyment literacki, teorie interpretacji. Autorka 
książki Dwudziestowieczna poezja polska $w$ kontekście anglo-amerykańskiego modernizmu. Słoje zadrzewne Tymoteusza Karpowicza i The Pisan Cantos Ezry Pounda (Lublin 2016). Stopień doktora uzyskany na podstawie rozprawy "Otwieranie wszechświata”. Polska powojenna awangarda poetycka: Tymoteusz Karpowicz i Krystyna Miłobędzka. Publikowała m.in. w „Wielogłosie”, „Ruchu Literackim”, „Poznańskich Studiach Polonistycznych”, „Autobiografii”, a także w wielu monografiach wieloautorskich. 
